\title{
Risk Mitigation Effects for Mudhārabah Financing Accounting Treatment (Case Study at Bank "YIX" in Aceh)
}

\author{
Muslina1, Angga Syahputra ${ }^{2 *}$ \\ ${ }^{1,2}$ Faculty of Islamic Economics and Business, State Islamic \\ Institute of Lhokseumawe \\ *Corresponding author: anggasyahputra@iainlhokseumawe.ac.id
}

Article history

\author{
Received, 31 July 2021 \\ Revised 1, 10 Sept 2021 \\ Revised 2, 30 Nov 2021 \\ Accepted, 05 Dec 2021
}

\begin{abstract}
Mudharabah financing has a high level of risk caused by moral hazard and adverse selection. The existence of these two risks resulted in a simultaneous impact on the reputation and liquidity of the bank "YIX", thus requiring risk mitigation. On the other hand, the risk mitigation action raises the contradiction of PSAK No. 105 in particular the recognition of financing, profit sharing and expenses. This study was conducted qualitatively by observing the phenomenon at the bank "YIX" and then describing it in the form of a combination of descriptions of the results of interviews, documentation and observations. The results of this study on risk mitigation measures for the accounting treatment of Mudharabah Financing have a negative effect, which is contrary to the statement of PSAK No. 105 Paragraph 12: recognition of mudharabah investments as investments; paragraph 22: does not justify recognizing profits from projected results of operations; paragraph 13 point c: does not allow charging fees without an agreement. If this is not mitigated, then the impact of financing risk will not only affect operations, but also reputation and even the potential for the loss of customers or investors because they are not prepared for the loss of funds due to the comprehensive application of the Mudharabah Financing concept. This concept can be a reference material for other banks in dealing with the impact of mitigation mitigation.
\end{abstract}

Keywords: Mitigation risk; treatment; accounting, financing, mudhārabah

\section{Cite this article:}

Muslina., Syahputra, A. (2021). Risk Mitigation Effects for Mudharabah Financing Accounting Treatment (Case Study at Bank "YIX" in Aceh), Jurnal Al-Qardh, 6(2), 1-13. pISSN: 2354-6034 https://doi.org/10.23971/iaq.v6i2.3144

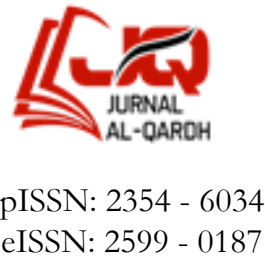

\section{Introduction}

Islamic banking is a manifestation of universal Islamic macro values. The existence of these values makes Islamic banking an intermediary institution that is fair, maslahab and free from activities prohibited by Islamic law such as usury, maysir, gharar and other speculative activities. ${ }^{1}$ The embodiment of this value can be seen from the operational system of Islamic banking, namely profit sharing, buying and selling, leasing, trusting and other services. Through this system, Islamic banking has enormous potential to develop a sense of social responsibility, social justice and national stability which is an absolute

${ }^{1}$ Ascarya, Akad dan Produk Bank Syariah, Edisi I, Cet. IV, (Jakarta: Rajawali Pers, 2013), p. 30. 
requirement for the emergence of banking commitments to support economic restructuring programs. These responsibilities can be realized, among others, by applying the concept of profit sharing so that there are no gaps in society.

One of the efforts of Islamic banking to avoid inequality in society is to apply Mudharabah financing. Mudharabah financing at the bank provides full investment or working capital (trusty financing), while the customer provides the project and its management. ${ }^{2}$ Assessing the financing concept, the bank will bear a high risk due to the absence of collateral provisions, plus the risk of moral hazard and adverse selection (misuse of credit facilities) as well as the limited technical competence of banks in assessing projects. ${ }^{3}$ In addition, mudharabah financing highly upholds the creation of justice between mudhārib (customers) and shahibul mal (Islamic banks). This reality requires Islamic banks to be careful and even seem to shift financing facilities to other contracts such as murabahah, musyarakah and ijarah. This can be seen from the Islamic Banking Statistics $2020 .^{4}$

Figure 1. Comparison of Financing in Islamic Banking

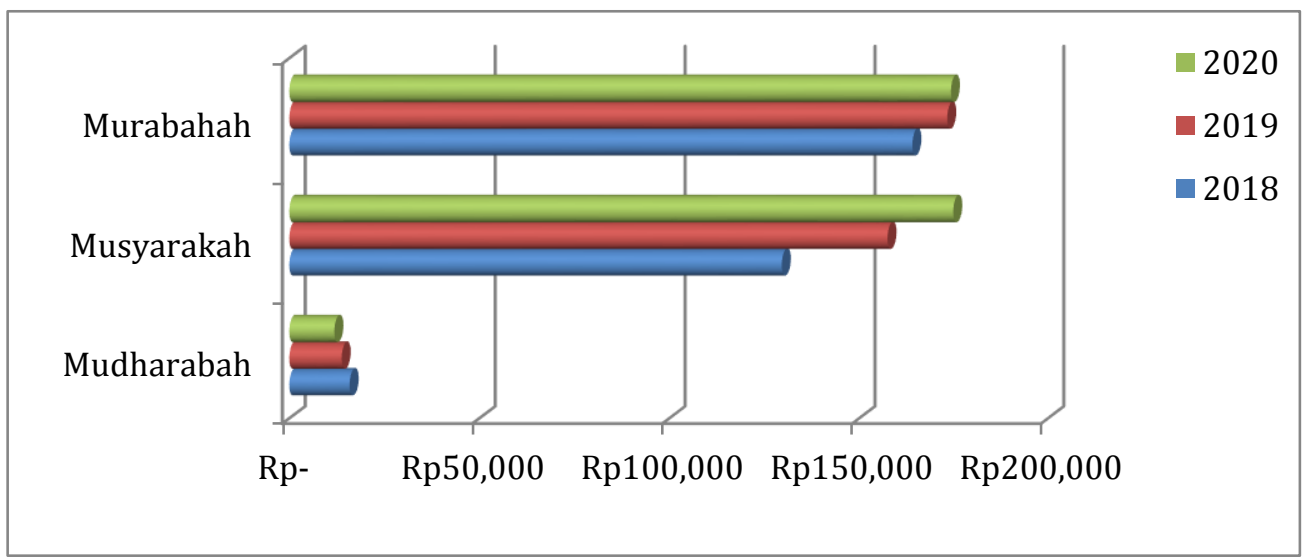

The picture above shows the gap in the allocation of financing in Islamic banking between musyarakah, murabahah and mudharabah financing. This is quite reasonable when reviewing several studies related to mudharabah financing, such as the research of Iwan Fahri Cahyadi. According to Iwan, the financing that bears the most risk is mudharabah financing so it must be controlled to obtain optimum profits. ${ }^{5}$ One way to control this risk is to divert most of the financing to lower risk fund distribution products, such as musyarakah financing. This is done to optimize profits from funds managed by banks. As the results of Widayati's research show that the level of risk of mudharabah financing has a significant effect on the profitability of Islamic banking compared to the level of risk of musyarakah financing ${ }^{6}$. Likewise, Sudirman Sappara's research which says that mudharabah

${ }^{2}$ Yadi Janwari, Lembaga Kenangan Syariah, (Bandung: Remaja Rosdakarya, 2015), p. 65

${ }^{3}$ Tariqullah Khan dan Habib Ahmed, Manajemen Resiko Lembaga Keuangan Bank Syariah, Cet. 1, (Jakarta: Bumi Aksara, 2008), p. 57

${ }^{4}$ Otoritas Jasa Keuangan, Statitik Perbankan Syariah Desember 2020, https://www.ojk.go.id, accessed on May $20^{\text {th }} 2020$

5Iwan Fahri Cahyadi, "Pengelolaan Manajemen Resiko sebagai Upaya Tindakan Preventif pada Pembiayaan Mudharabah", Tawazun: Journal of Sharia Economic Law, Vol. 2 No. 2 (2019).

${ }^{6}$ Neneng Widayati, "Pengaruh Tingkat Resiko Pembiayaan Mudharabah, Musyarakah dan Murabahah terhadap Profitabilitas pada Bank Syariah Mandiri dan Muamalah Periode 2013-2017”, Jurnal Ekonomi Bisnis, Vol. 26 No.1 (2020) 
financing places the first risk compared to other financing. ${ }^{7}$ In addition, there is no Investment Guarantee Institution that makes Islamic banks feel reluctant to provide investment in this form of financing. Currently, the solution adopted by Islamic banking today is to protect the risk of mudharabah financing by cooperating with the insurance company. However, another problem arises, namely that the funds taken from premium payments for risk protection are charged to the customer as a borrower (mudharib). The solution is applied to almost all Islamic banking in Indonesia, including Islamic Commercial Banks, Sharia Business Units and Sharia People's Financing Banks, including YIX bank. ${ }^{8}$

The complexity of the risk above has an impact on the accounting treatment of Mudharabah Financing. As stated in PSAK No. 105, it has been explained that expenses incurred in connection with the mudharabah contract cannot be recognized as part of the mudharabah financing, unless there is an agreement. ${ }^{9}$ However, it is not explained further what expenses are included in the statement, and whether this also includes premium expenses as a result of cooperation between insurance parties to protect the risk of mudharabah financing. If true, then where lies the justice in the accounting treatment applied by the Islamic bank, isn't that the only interest of the bank which never wants to be harmed. Then where is the role of the bank that acts as shabibul maal who also bears the loss if the business run by the mudharib suffers a loss as long as it is not due to negligence and intentional. Moving on from these problems, researchers are encouraged to analyze the Effects of Risk Mitigation for the Accounting Treatment of the Application of Mudharabah Financing. This study is a case study, in that the researcher moves from the existence of a case and then compares it with Islamic accounting standards, especially PSAK No. 105. Similar studies have been conducted by Muhammad Robi et al ${ }^{10}$ concerning Evaluation of Mudharabah Transactions based on PSAK No. 105 in Islamic Banks", however, the research thoroughly analyzes the implementation of PSAK No. 105 in Islamic banks. It is different with Rohman and Agustina who specifically research "Implementation of Profit-Sharing System and Accounting Treatment of Mudharabah Financing at KSPPS BMT An-Nuur Jombang". ${ }^{11}$

\section{Research Methods}

This research approach is qualitative by observing field phenomena through case studies. The case raised is one that occurred in a bank in Aceh with primary data sources from interviews and observations. Meanwhile, secondary data comes from documentation and literature review. The parties interviewed were the head of the financing section, account officer, head of operations, accounting department, and deputy director of the bank "YIX". After all data has been collected, both primary and secondary data, then the

\footnotetext{
${ }^{7}$ Sudirman Sappara, "Risk Analysis of Mudharabah Financing and Sharia Banking Musyarakah at PT. Bank BRI Syariah Tbk Listed on the Stock Exchange (IDX)", PAY: Journal of Finance and Banking, Vol 3 No. 1 (2021)

${ }^{8}$ YIX Bank is a pseudonym for the bank to protect the good name of the bank that is the object of the case study

'Ikatan Akuntan Indonesia, Standart Akuntansi Kenangan, Jilid 1, (Jakarta: Salemba Empat, 2009), p. 2

${ }^{10}$ Muhammad Robi dkk, "Evaluasi Transaksi Mudharabah Berdasarkan PSAK 105 pada Bank Syariah", Budgeting: Jurnal of Business, Management and Accounting, Vol. 2, No. 2 (2021).

${ }^{11}$ Miftakhul Rohman dan Rachma Agustina, "Impelementasi Sistem Bagi Hasil dan Perlakuan Akuntansi pada Pembiayaan Mudharabah di KSPPS BMT An-Nuur Jombang”, JFAS: Journal of Finance and Accounting Studies, Vol.3, No. 1 (2021),
} 
final stage is to analyze all data using descriptive methods and ensure the saturation of the data in the field through research credibility testing.

\section{Literature Review \\ Mudharabah Financing Risk Management}

Financing risk is often referred to as the risk of default from the customer, but specifically for profit-sharing-based financing products such as mudharabah, this risk is not included in the category that must be handled. This is because the mudharabah concept does not require customers to return capital but requires customers to share profits and losses based on the realization of the business being carried out. If the business is profitable, the customer can return the capital in full as well as the agreed profit with the profit sharing ratio that has been set at the beginning of the contract. However, if the business loses, then the capital will also bear the loss and cannot be returned by the customer. The risk faced in mudharabah financing is the risk of human error due to violation (fraud) or negligence (error). This risk is more due to an error in the selection of debtors, thus obtaining debtors who are less trustworthy and professional which allows them to carry out moral hazard or mismanagement. ${ }^{12}$

Mudharabah financing has a high level of risk so it requires a reliable mitigation strategy ranging from assessment to risk evaluation in order to minimize the impact of losses for the company. The aspects of the assessment include the quality of partners, types and business activities and business continuity of partners. ${ }^{13}$ Meanwhile, in the evaluation aspect, investors must conduct a feasibility test, namely an evaluation of the risk profile, Human Resources (SDI) and the business activities being carried out. ${ }^{14}$ All of this is done to avoid asymmetric information that has the potential to cause moral hazard and adverse selection from investors. One of the steps to anticipate the risk due to moral hazard investors is to establish a covenant (cause) when entering into a Mudharabah Financing contract. ${ }^{15}$ Other anticipatory steps that can be taken are binding the mudharib with collateral, providing conditions for the mudharib to do business with low risk or requiring cash flow transparency. ${ }^{16}$

\section{Mudharabah Financing Accounting}

Accounting is a process to recognize, measure, record and disclose fairly that adheres to God's provisions so that it can be used for decision making. This is in line with what was stated by Wiroso about accounting, namely the recognition, measurement, recording of transactions in accordance with rights and obligations fairly. ${ }^{17}$ Islamic accounting has the following objectives: ${ }^{18}$

a. Determine the rights and obligations of related parties, including rights and obligations for unfinished transactions or other economic activities in accordance

\footnotetext{
${ }^{12}$ Imam Wahyudi dkk, Manajemen Resiko Bank Islam, (Jakarta: Salemba Empat, 2013), p. 177.

${ }^{13}$ Bambang Rianto Rustam, Manajemen Resiko Pembiayaan Perbankan Syariab di Indonesia, Jakarta: Salemba Empat, 2013), p. 260.

${ }^{14}$ Rustam, Manajemen.., p. 261.

15Muhammad, Manajemen Bank Syariah, (Yogyakarta: UPP STIM YKPN, 2011), p. 367.

${ }^{16}$ Ibid., p. 371-372.

${ }^{17}$ Wiroso, Akuntansi Transaksi Syariah, (Jakarta: Ikatan Akuntan Indonesia, 2011), p. 15.

${ }^{18}$ Sofyan Syafri Harahap, Akuntansi Perbankan Syariah, Cet. I, (Jakarta: LPEF Usakti, 2004), p. 21.
} 
with sharia principles based on the concepts of honesty, fairness, policy and adherence to Islamic business values.

b. Provide useful information for users of financial statements in making decisions.

c. Improve compliance with sharia principles in all transactions and business activities.

In addition to the above objectives, the recording or accounting system also aims for the following: ${ }^{19}$

a. Ensuring the security and safety of Islamic bank assets, including guaranteeing the rights of banks and the rights of other stakeholders.

b. Ensuring the improvement of management and productive capability of Islamic banks so that they are always in line with the goals and policies that have been set.

The general principles contained in Islamic banking accounting are as follows: ${ }^{20}$

a. Principle of responsibility

The principle of responsibility in Islamic banking accounting is closely related to the concept of trust. This concept of trust is a consequence of human duty as God's vicegerent on this earth who carries out all obligations and recommendations and stays away from all His prohibitions. The implication of this trust concept in a business and accounting system is that every individual involved in the business must always take responsibility for what has been mandated and strengthened by the relevant parties. The form of this responsibility is in the form of financial statements.

b. Principle of justice

The principle of justice is an ethical value that is very important in social and business life and this principle is also inherent in human nature which has the capacity and energy to do justice in every aspect of life. When viewed in the Qur'anic affirmation of this principle of justice, it has been stated explicitly in the Surah alBaqarah verse 282: "... and let a writer among you write it right. And let the writer not be reluctant to write it down as Allah has taught him, so let him write." In simple terms, this paragraph emphasizes that every transaction made by a company or individual should be properly recorded. Likewise, with Islamic banking as a public institution whose information is needed by many parties, both customers, government, shareholders, DPS and other parties. If the transaction is not recorded correctly, then the result will not be guaranteed justice in it because justice depends on honesty and if the Islamic bank is honest, then it will record correctly.

c. Principle of truth

The principle of truth is closely related to the application of justice in conveying accounting information. This is because in accounting we will always be faced with the problem of recognizing, measuring and reporting economic transactions. This activity cannot be carried out properly if it is not based on truth values. And the value of truth will guarantee the creation of justice in recognizing, measuring and reporting economic transactions.

Based on these general principles, these general principles give birth to special principles in sharia accounting, namely the three principles above will be realized in the recording of transactions if the transactions are recorded correctly, quickly, clearly, clearly, concisely and informatively; thorough; addressed to all parties; detailed and thorough; there

\footnotetext{
${ }^{19}$ Kuat Ismanto, Manajemen Syariah: Implementasi TMQ Dalam Lembaga Keuangan Syariah, Cet. I, (Yogkarta: Pustaka Pelajar, 2009), p. 123.

${ }^{20}$ Muhammad, Pengantar Akuntansi Syariah, (Jakarta: Salemba Empat, 2002), p. 11-12.
} 
is no element of manipulation; and carried out continuously. ${ }^{21}$ The accounting standard used to recognize, measure, present and disclose Mudharabah Financing transactions is Statement of Financial Accounting Standards No.105. The scope of PSAK No. 105 Mudharabah Accounting includes: $:^{22}$

1. This statement is applied to entities that carry out mudharabah transactions both as owners of funds (shahibul maal) and managers of funds (mudhārib);

2. This statement does not cover accounting treatment arrangements for Islamic bonds (sukuk) that use mudharabah contracts.

PSAK Statement No. 105 is an amalgamation of PSAK No. 59 which aims to describe the accounting treatment in detail in order to make it easier for Islamic financial institutions to apply in the treatment of their transactions. For this reason, in 2007 PSAK No. 105 was inaugurated by the Islamic Accounting Standards Board of the Indonesian Institute of Accountants (DSAS-IAI). The statement must be applied by all financial institutions, especially Islamic financial institutions in Indonesia. The function of PSAK No. 105 is a tool for recognizing, measuring, recording, disclosing and presenting financial transactions, especially mudharabah financing in order to produce fair and useful information for its users. Here are the details of his statement: ${ }^{23}$

A. Recognition and Measurement of Mudharabah Financing

(1) Mudharabah funds distributed by fund owners are recognized as Mudharabah Investments at the time of cash payment or delivery of non-cast assets to the fund manager.

(2) Mudharabah investment measurement is as follows:

a) Mudharabah investment in cash is measured at the amount offered.

b) Mudharabah investments in the form of non-cash assets are measured at the fair value of the non-cash assets at the time of delivery:

i. If the fair value is higher than the carrying amount, the difference is recognized as deferred gain and amortized over the term of the mudharabah contract.

ii. If the fair value is lower than the carrying amount, the difference is recognized as a loss.

c) Expenses incurred in connection with Mudharabah Investments cannot be recognized as part of Mudharabah Investments unless mutually agreed.

(3) If the value of the mudharabah asset decreases before the start of the business due to damage, loss or other factors that are not the negligence or fault of the fund manager, then the decrease is recognized as a loss and reduces the balance of the mudharabah investment.

(4) If part of the mudharabah investment is lost after the start of the business without any negligence or error by the fund manager, then the loss is calculated at the time of profit sharing.

(5) The mudharabah business is considered to be running since the funds or mudharabah business capital are received by the fund manager.

(6) In mudharabah investments that are given in non-cash assets and non-cash assets are impaired when or after the goods are used effectively in mudharabah

\footnotetext{
${ }^{21}$ Ibid, p. 62

${ }^{22}$ Ikatan Akuntan Indonesia, Standar Akuntasi Keuangan, (Jakarta: Selemba Empat, 2009), p. 200.

${ }^{23}$ Ibid., p. 209.
} 
business activities, the losses do not directly reduce the investment amount, but are calculated at the time of distribution of operating results.

(7) Errors in the fund manager's error, among others, are aimed at:

a) The requirements specified in the contract are not met;

b) There are no conditions beyond the usual capacity (force majeure) or those specified in the contract;

c) The result of the decision of the competent institution.

(8) If the mudharabah contract expires before or when the contract is due and has not been paid by the fund manager, the mudharabah investment is recognized as a receivable.

(9) If the mudharabah investments exceeds one reporting period, operating income is recognized in the period in which the profit-sharing rights occur in accordance with the agreed ratio.

(10) Losses incurred in a period prior to the expiration of the mudharabah contract are recognized as losses and an investment loss allowance is provided. At the end of the mudharabah contract, the difference between:

a) Mudharabah investment after deducting Allowance for Losses on mudharabah investments;

b) Return on Investment Mudharabah is recognized as gain and loss.

(11) Recognition of mudharabah operating income in practice can be known based on the operating profit-sharing report on the realization of operating income from the fund manager, it is not allowed to recognize income from projected operating results.

(12) Losses due to negligence and errors of the fund manager are borne by the fund manager and do not reduce the balance of the Mudharabah Investment.

(13) Profit sharing that has not been paid by the fund manager is recognized as receivables.

B. Presentation of mudharabah financing

(1) The owner of the fund presents the mudharabah investments in the financial statements at the carrying amount.

(2) The fund manager presents mudharabah transactions in the financial statements, but is not limited to:

a) Temporary syirkah funds from fund owners are presented at the nominal amount for each type of mudharabah;

b) Temporary syirkah funds that have been calculated and have matured but have not been handed over to the owner of the funds are presented as liabilities; and

c) Profit sharing of temporary syirkah funds that have been calculated but have not yet matured are presented in the profit-sharing account that has not been distributed.

C. Mudharabah financing Disclosure

The owner of the fund discloses matters related to mudharabah transactions, but is not limited to the following:

(1) The contents of the main agreement for the mudharabah business, such as the portion of funds, the distribution of business results, mudharabah business activities and others;

(2) Details of the amount of mudharabah investments by type;

(3) Allowance for mudharabah investments losses during the current period; and 
(4) The required disclosures are in accordance with PSAK No. 101 regarding the presentation of Islamic financial statements.

Explanation of PSAK No. 105 according to PAPSI in 2003 are as follows: ${ }^{24}$

(1) Mudhārabah consists of two types, namely mudhārabah muthlaqah (unrestricted investment) and mudhārabah muqayyadah (bound investment). This chapter only discusses banks as shahibul mal (fund owners) in mudhārabah financing, while banks as mudhārib (fund managers) are discussed in unrestricted investment posts. For banks as investment agents (channelling) in mudhārabah muqayyadah, it is discussed in the Report on Changes in Bound Investments in the off balance sheet, while banks as parties who share in the risk (executing) in mudhārabah muqāyyadah are discussed in the Restricted Investment Liabilities heading.

(2) Mudharabah financing can be provided in the form of cash and or non-cash which is carried out in stages or all at once.

(3) The return of mudharabah financing can be done simultaneously with the distribution of profit sharing or at the termination of the mudharabah contract.

(4) Mudharabah profit sharing can be done using two methods, namely profit sharing or revenue sharing. Profit sharing is calculated from income after deducting expenses related to the management of mudharabah funds. As for income, it is calculated from the total income of mudharabah management.

(5) In the event of a loss in the fund management business (mudhārib), the bank as the owner of the funds (shahibul mal) will bear all losses as long as the loss is not caused by negligence or error of the fund manager (mudhārib).

(6) In principle, in mudharabah financing there is no requirement for a guarantee, but in order to avoid moral hazard in the form of irregularities by the fund manager, the fund owner can ask for a guarantee from the fund manager or a third party. This guarantee can only be disbursed if the fund manager is proven to have violated the things that have been mutually agreed upon in the contract.

(7) Recognition of mudharabah profit or loss in practice can be known based on profit sharing reports from fund managers that are received by the bank on a regular basis in accordance with the agreement.

\section{Results and Discussion}

\section{Accounting for Mudharabah Financing at Bank "YIX" in Aceh}

The accounting simulation of Mudharabah Financing at Bank "YIX" in Aceh can be described as follows: Mr. Suryadi applied for financing with a mudharabah contract at Bank "YIX", he needed funds for contractor activities of Rp. 200.000.000, on January 13, 2013 the bank approved the request and followed up by conducting a field survey. Based on the results of the survey and assessment of bank guarantees, the amount of funds requested by Mr. Suryadi was approved for a period of 4 months starting from February. In accordance with the assumption, the profit sharing has been set at $30 \%$ of the total profit to be obtained at Rp. 20.000.000, so Mr. Suryadi will pay Rp. 6.000 .000 at the end of the maturity

\footnotetext{
${ }^{24}$ Bank Indonesia, Pedoman Akuntansi Perbankan Syariah Indonesia Tabun 2003, Publikasi BI Juli 2003, http:/ /www.bi.co.id, accessed on January $20^{\text {th }} 2013$, p. 56-60.
} 
date, which is May 31, 2013. The provisions that apply to Bank "YIX" are that customers are required to pay the following fees: $:^{25}$

- 2\% administration fee x Rp. 200.000.000

: Rp. 2.000 .000

- Notary fee

:Rp. $\quad 500.000$

- Stamp fee

: Rp. $\quad 40.000$

- Insurance fee

: Rp. $\quad 300.000$

Thus, bank "YIX" will record as follows:

\begin{tabular}{|c|c|c|c|}
\hline $\mathrm{NO}$ & ACCOUNT & DEBET & CREDIT \\
\hline \multirow[t]{3}{*}{1} & Customer Savings & 2.000 .000 & \\
\hline & - Administration Revenue & & 2.000 .000 \\
\hline & $\begin{array}{l}\text { (Receipt of payment of administration fee } \\
\text { from customer) }\end{array}$ & & \\
\hline \multirow[t]{3}{*}{2} & Customer Savings & 500.000 & \\
\hline & - Notary Savings Account & & 500.000 \\
\hline & $\begin{array}{l}\text { (Receipt of payment of notary fees from } \\
\text { customers) }\end{array}$ & & \\
\hline \multirow[t]{3}{*}{3} & Customer Savings & 40.000 & \\
\hline & - Stamp Income & & 40.000 \\
\hline & $\begin{array}{l}\text { (Receipt of stamp duty payment from } \\
\text { customer) }\end{array}$ & & \\
\hline \multirow[t]{3}{*}{4} & Customer Savings & 300.000 & \\
\hline & - Insurance Savings Account & & 300.000 \\
\hline & $\begin{array}{l}\text { Receipt of insurance fee payment by } \\
\text { customer) }\end{array}$ & & \\
\hline \multirow[t]{3}{*}{5} & Insurance Savings Account & 10.000 & \\
\hline & - Insurance fee income & & 10.000 \\
\hline & (Receipt of insurance fee by the Bank) & & \\
\hline \multirow[t]{3}{*}{6} & Notary Savings Account & 25.000 & \\
\hline & - Notary fee income & & 25.000 \\
\hline & (Receipt of a notary fee by the bank) & & \\
\hline \multirow[t]{3}{*}{7} & Mudharabah Financing & 200.000 .000 & \\
\hline & - Customer Saving Account & & 200.000 .000 \\
\hline & $\begin{array}{l}\text { (receipt of disbursement of financing funds } \\
\text { by customers) }\end{array}$ & & \\
\hline \multirow[t]{3}{*}{8} & Customer Saving Account & 6.000 .000 & \\
\hline & - Income for Mudharabah. Financing & & 6.000 .000 \\
\hline & (Receipt of revenue sharing from customers) & & \\
\hline \multirow[t]{3}{*}{9} & Customer Saving Account & 200.000 .000 & \\
\hline & - Mudharabah Financing & & 200.000 .000 \\
\hline & $\begin{array}{l}\text { (Receipt of principal refund of Mudharabah } \\
\text { Financing) }\end{array}$ & & \\
\hline
\end{tabular}

The series of accounting treatments above have largely complied with the provisions of PSAK No. 105 from recognition, measurement, presentation and disclosure. However, if studied in depth, there are several things that have not been perfect in adopting the provisions of PSAK No. 105, this is more due to the risk mitigation action of Mudharabah Financing.

\footnotetext{
${ }^{25}$ The results of observations, documentation and interviews with the Financing, Legal and Accounting sections at Bank "YIX" in Aceh.
} 


\section{The Effect of Risk Mitigation for the Accounting Treatment of Mudharabah Financing at the "YIX" Bank in Aceh}

Islamic banks are banks that carry out their operational activities based on Islamic economic principles. Therefore it is required for Islamic banks to apply the concepts of Islamic transactions. However, its existence which is still relatively new makes Islamic banks have to compete with conventional banks that have been known by the public first. If Islamic banks carry out their activities without complying with the provisions of Islamic economics, then support from various parties is needed so that Islamic banks become more perfect in implementing sharia principles. Among the important principles that must be applied to Islamic bank financing products is the mudharabah contract principle because one of the advantages of Islamic banks is to offer products with mudharabah contracts.

In concept, mudharabah financing is financing provided by Islamic banks to customers who need funds to be channeled in a particular business or project, where the bank bears all the capital needed by the customer, while the customer only acts as a mudhārib who has the expertise to manage the capital. This financing has consequences for losses that will be borne together, namely the bank acting as shabibul maal will bear the loss of the capital that has been distributed and the mudhārib will bear the loss of time and energy that he has channeled in the business. However, the above provisions will apply if the loss is not caused by the fault and negligence of the customer (mudharib). Meanwhile, the profits generated from these businesses and projects will be shared based on an agreement.

However, the above provisions are not always the same as the reality that occurs in Islamic banking, there are many mistakes that violate the initial concept of mudharabah financing, including mudharabah financing as additional working capital, not initial capital that is fully provided to be managed by customers, where customers already have their own capital and need supporting capital from the banking sector. If so, then this concept is more in line with the musharakah contract, which is a contract that requires each party to combine their capital according to their abilities. Another mistake is the determination of profit sharing which is determined based on assumptions based on the results of the initial survey from the financing stage and the amount will be fixed and paid on a monthly basis or at maturity. Both of these things have made this contract look flawed and consequently resulted in the invalidity of the contract. In addition, the two statements above also have consequences for violating the provisions of PSAK No. 105, among the violations are as follows:

1. PSAK No. 105 states that mudharabah financing cannot be recognized as a receivable, but Islamic banks treat it as a receivable that must be paid by the customer, otherwise the bank will sell the guarantee or extend the maturity until the customer is able to pay it. Thus, the journals applicable to Islamic banks are:

Mudharabah financing receivables $\mathrm{xxx}$
- Customer savings
XXX

The above treatment is due to the crisis of trust, which is increasingly becoming a social phenomenon, where moral hazard is becoming a separate trend, such as fraud, corruption and other criminal cases.

2. The determination of the profit sharing of mudharabah financing in Islamic banks also does not show the consequences of the financing, but the bank determines it based on assumptions not based on actual income, while the statement of PSAK No. 105 states that the profit sharing of mudharabah financing is based on the reality of the income obtained, not based on the assumption of the income earned. This has consequences for 
the recording of the same amount, for example, based on the initial assumption that the customer is obliged to pay profit sharing to the bank of Rp. 150.000 with the following records:

Customer Saving Account

-Revenue Sharing
Rp. 150.000

Rp. 150.000

The series of cases above are risk mitigation measures implemented at Bank "YIX" in order to eliminate the impact on the company because mudharabah financing has systemic risks that not only affect operations, but also the reputation and liquidity of the company. If the bank does not require guarantees and full refunds, there is the potential for some funds to be lost due to customer losses. Likewise with determining profits based on assumptions, this is done by the parties because of the difficulty of obtaining comprehensive financial information from customers. In addition, mudharabah financing is not supported by the Investment Guarantee Institution which guarantees the integrity of the return of investment funds to Islamic banks. This affects the reputation of the banking system if the Non-Performing Financing (NPF) of the Bank "YIX" is high, then the bank is in the unhealthy category, resulting in a drop in stock prices. Furthermore, the high NPF also raises the risk of liquidation as a result of the loss of cash that has been disbursed. The biggest consequence for the bank "YIX" is the loss of customers and investors and it is not impossible that they will switch to conventional banks because customers and investors are not ready and accustomed to bear losses from their investments.

Another mitigation action of Bank "YIX" is to protect its risks by cooperating with insurance companies, in which the burden of insurance costs is transferred to borrowing customers, so that the bank is never harmed and the bank will also receive a fee from the results of the cooperation. This makes the customer very disadvantaged because he never received the insurance claim even though he had returned the principal and profit sharing. In addition, this fee is not based on an agreement, but an obligation imposed as a result of taking mudharabah financing. If the customer does not agree to bear this cost, the bank will assume that the customer does not comply with the provisions applicable to the bank, so this financing will not be provided.

The above fact is very contrary to the following accounting statement for mudharabah financing: "Expenses incurred in connection with mudharabah investment cannot be recognized as part of mudharabah financing unless mutually agreed". This statement gives rise to multiple interpretations, namely the permissibility of charging any fees based on an agreement without having to consider compliance with the principles of muamalah in Islam. When associated with the imposition of insurance costs (risk protection costs), the imposition of insurance costs is considered something that does not conflict with the provisions of PSAK No. 105. This makes the loss of the principles that must be adhered to in Islamic muamalah, namely:

1) The principle of unity, this principle has consequences for the application of the values of monotheism in business transactions, namely everything that is done only to hope for the pleasure of Allah Swt.

2) The principle of permissibility, this principle has the consequence that all things in muamalah activities may be done unless there are provisions that prohibit it.

3) The principle of justice, this principle has the consequence that the transactions carried out must be transparent, honest and set costs fairly so as not to harm one party. 
4) The principle of responsibility, namely this principle which gives consequences to the responsibility for every transaction activity carried out, both in fulfilling its obligations and accountability in the form of reports.

5) The principle of truth, namely this principle which has consequences for all activities carried out must be based on virtue and honesty both in the contract process, the process of seeking or obtaining commodities, the development process as well as in the process of achieving or setting profit margins (profit).

6) The principle of willingness is this principle which gives the consequence that every individual gets the freedom to choose and choose something voluntarily.

When referring to the principles mentioned above, the imposition of insurance costs is contrary to the principles of unity (tawhid), justice and willingness because the imposition of these costs causes losses to customers and the bank never feels a loss. Based on this reality, further studies are needed regarding the limits of the agreement that are justified in Islamic muamalah transactions, so that the existing agreement does not favor the benefit of one party and harm the other party.

\section{Conclusion}

Mudharabah financing contains systemic risks to the operational, reputation and even liquidity of Islamic banks. The magnitude of the impact on the company forced the Bank "YIX" to mitigate risks comprehensively starting from its assessment, implementation to control. However, risk mitigation measures for mudhārabah financing at Bank "YIX" have a negative effect on the accounting treatment of mudhārabah financing, namely there are several conflicts with PSAK No. 105 in the case of recognizing mudharabah financing as receivables and recognizing profits based on initial projections as well as charging insurance costs to customers. If referring to PSAK No. 105 Paragraph 12, the distribution of "mudharabah financing is recognized as an investment" not as a receivable. Likewise, the recognition of profits in paragraph 22 states "it is not allowed to recognize income from business projections". Likewise with the concept of agreement built on the "YIX" bank, especially in the case of charging insurance costs to customers causing customer losses, so that the interpretation of the statement "Expenses incurred in connection with mudharabah investments cannot be recognized as part of mudharabah financing unless mutually agreed upon" requires a study of agreement limits permitted by sharia.

This research is the result of collaboration with the bank "YIX" as well as colleagues and lecturers of IAIN Lhokseumawe who have provided direction and guidance, hopefully their contributions can provide benefits for the advancement of knowledge and Islamic economics.

\section{References}

Ascarya. (2013). Akad dan Produk Bank Syariah. Edisi I. Cet. IV Jakarta: Rajawali Pers. Cahyadi, Iwan Fahri. (2019). "Pengelolaan Manajemen Resiko sebagai Upaya Tindakan Preventif pada Pembiayaan Mudharabah", Tawazun: Journal of Sharia Economic Law, Vol. 2 No. 2

Harahap, Sofyan Syafri. (2004). Akuntansi Perbankan Syariah. Cet. I. Jakarta: LPEF Usakti.

Ikatan Akuntan Indonesia. (2009). Standart Akuntansi Keuangan. Jilid 1. Jakarta: Salemba Empat. . (2009). Standar Akuntasi Keuangan. Jakarta: Selemba Empat. 
Ismanto, Kuat. (2009). Manajemen Syariah: Implementasi TMQ Dalam Lembaga Keuangan Syariah. Cet. I. Yogkarta: Pustaka Pelajar.

Janwari, Yadi. (2015). Lembaga Kenangan Syariah. Bandung: Remaja Rosdakarya.

Khan, Tariqullah and Ahmed, Habib. (2008). Manajemen Resiko Lembaga Keuangan Bank

Syariah. Cet. 1. Jakarta: Bumi Aksara.

Muhammad. (2002). Pengantar Akuntansi Syariah. Jakarta: Salemba Empat. . (2011). Manajemen Bank Syariah. Yogyakarta: UPP STIM YKPN,

Otoritas Jasa Keuangan. (2020). Statitik Perbankan Syariab Desember 2020. https://www.ojk.go.id, accessed on May 20 ${ }^{\text {th }}, 2020$. . (2013). Pedoman Akuntansi Perbankan Syariab Indonesia Tabun 2013.

http://www.ojk.go.id, accessed on July $28^{\text {th }} 2021$.

Robi, Muhammad et al. (2021). "Evaluasi Transaksi Mudharabah Berdasarkan PSAK 105

pada Bank Syariah". Budgeting: Jurnal of Business, Management and Accounting, Vol. 2,

No. 2

Rohman, Miftakhul and Agustina, Rachma. (2021). "Impelementasi Sistem Bagi Hasil dan Perlakuan Akuntansi pada Pembiayaan Mudharabah di KSPPS BMT An-Nuur Jombang”. JFAS: Journal of Finance and Accounting Studies, Vol. 3, No. 1

Rustam, Bambang Rianto. (2013). Manajemen Resiko Pembiayaan Perbankan Syariah di

Indonesia. Jakarta: Salemba Empat.

Sappara, Sudirman. (2021). "Analisis Resiko Pembiayaan Mudharabah dan Musyarakah Perbankan Syariah pada PT. Bank BRI Syariah Tbk Yang Terdaftar di Bursa Efek

(BEI). PAY: Jurnal Kenangan dan Perbankan, Vol 3 No. 1

Wahyudi, Imam et al. (2013). Manajemen Resiko Bank Islam. Jakarta: Salemba Empat..

Widayati, Neneng. (2020). "Pengaruh Tingkat Resiko Pembiayaan Mudharabah, Musyarakah dan Murabahah terhadap Profitabilitas pada Bank Syariah Mandiri dan Muamalah Periode 2013-2017'”. Jurnal Ekonomi Bisnis. Vol. 26 No.1

Wiroso. (2011). Akuntansi Transaksi Syariah. Jakarta: Ikatan Akuntan Indonesia 